\title{
The sizes of truth: how Ivan Sen's Wind helps us understand a complex contemporary identity
}

\author{
Anita Donovan \\ University of Technology Sydney, Faculty of Arts and Social Sciences, PO Box 123, Ultimo NSW \\ 2017, Australia. anita.donovan@student.uts.edu.au
}

DOI: $\underline{\text { https://doi.org/10.5130/nesais.v4i1.1506 }}$

Set in 1867, Ivan Sen's short film Wind tells the story of a young Indigenous tracker named Jess who, in the process of hunting a wanted criminal with his sergeant, begins to trace the footsteps of a community and a heritage he has barely known. This story is set entirely in the mountains, with few references to the wider contexts of Jess and the sergeant, placing it almost completely apart from the plateaus of central 'big' truths (Read 2002, p. 54) that constitute the crux of Aboriginal Australian history. Jess' story acts as a representation of one of the complex anomalies that were a part of early frontier life. It not only tells, but shows audiences that it's just not that simple.

Ernie Blackmore states that "for 'mainstream' Australia, 'authentic' Aboriginal culture and identity are located in the past, whereas contemporary Aboriginal life is degraded, 'inauthentic', and unable to negotiate the modern world" (2014, p. 66). This film somewhat turns the mainstream lens on its head; set in a time commonly known as the only point of reference for what that authentic traditional culture looked like, Jess wears a long woollen coat, a cap, a white tunic and trousers. He looks the part of most convict settlers and he travels amiably with a white sergeant. There is a harmony between them; Sen focuses closely in the opening shots on Jess' body and quiet bare feet, followed by the heavy torso and sound of horse hooves, and then a suspended foot in a stirrup. These moments are presented as a fluid continuation of each other in the same way that the pair work in sync, the sergeant deferring to Jess' expertise and quietly letting him lead the way - not the traditional relationship of overt oppression white audiences might expect.

Wind has a strong focus on Aboriginal identity and how it evolves, particularly the influence of colonial history upon that evolution. Dispossession from land and removal of children from language groups is well documented as a part of cultural upheaval. However, the interplay of how Aboriginal culture embedded in existing communities within the Western culture that they were forced to become a part of is not - nor how people like Jess were caught in the middle of it.

Historians like Goodall found that during emerging frontier communities, tenuous understandings did exist between Aboriginal communities and white colonisers. For example, Warraweer's birthing and the contracts between Phillip and Bennelong, which indicated vastly unequal power imbalances, also 
demonstrated distinct "culturally created expectations on which they drew to try to interpret the other" (Goodall 1995, p. 63). The sergeant and Jess' relationship holds an imbalance of power: Jess is "boy" and the sergeant is "boss". Their connection is also palpable in the way the sergeant and Jess communicate wordlessly during the start of the film. The sergeant respects Jess' job as a tracker, which aids their companionship, but neither confront the relation Jess has to the man they are hunting, nor the imminent impact on their relationship when the sergeant enacts his duty as an enforcer. Both the companions describe the man they are tracking with a slur, implying that white culture is all Jess has ever really known and the only lens he has to see his ancestry through, with no other cultural expectations to draw upon. As for the sergeant, while the colonial culture included a belief that Aboriginal violence did not "emerge from the contingencies of the colonial frontier but existed as an essential part of their being" (Morris 1992, p. 15), his companionship shows he does not necessarily share this belief, differing from historical understandings of most white attitudes. He does overlook, however, as pastoralists did, how the cause of the violence was that of an owner protecting it from invasion, not a criminal on contested land (Goodall 1995). This is the tension in their companionship: the introduced and racialised binary of the frontier's views of justice, with the gun and the slur depicting the "technology and the arrogance which would later contribute to mistrust and anger" among early relations (Goodall 1995, p. 64).

When the two separate as part of the hunt, a change of pace occurs. A new figure appears while Jess sleeps by the horse, carrying a bloodied stone-headed weapon. Jess wakes, his eyeline immediately rising to exactly where the man stood, but it is a phantom connection; he is gone. This feeling of a spectral presence is persistent. When experiencing a nightmare, Jess' vision is rendered in a point-ofview shot tracking through the woods and discovering the cabin he and the sergeant occupy. Traditionally, this is used in a thriller or horror genre to give the impression of hunter and hunted, but Sen's use of it implies something more than mortality. Fear is elicited in Jess when he confronts his ancestry. It is the same when he places his hand flush onto a print in the cave and withdraws it, as if burned, spooked by what he senses there. The man on the mountain weeps when Jess places his hand on the cave wall, and the reason for his tears is best reflected in a quote from Galarrwuy Yunupingu: "It is a form of torture for a Yolngu person to see the loss of our life..." (Yunupingu 2016). To see a young boy who knows nothing of his language or people in the clothes of another world is a vision of destruction, and Jess is terrified by his peripheral awareness of this trauma.

The close focus is also pulled on the ferns, horse hooves, and the sand beneath Jess' hands, giving personality to his surroundings and depicting a relationship to the land that Jess hasn't realised the genesis of yet. For Jess, expertise in tracking is a skill, not an instinct. He is rewarded for his service by the sergeant when, knowing he is dying, hands over his cap like an heirloom to a son, he says "I want you to have it" (Sen 1999). This moment represents a coming-of-age for Jess as a fully functioning citizen of the white community through his exclusive ability to track, making it not so much an assimilation as an evolution. Unlike urban Aboriginal activists and populations of later years who were able to express that they "cherished an Aboriginal identity and sought an expansion of that identity," (McGregor 2011, p. 38), Jess is just starting to articulate an interplay between the two worlds.

The horse expresses solidarity in place of articulation; it is part of nature, but is native to the colonisers. Jess is meanwhile part of this land but his identity is streaked with influences, both good 
and bad, of colonisation. The horse returns to him when he discovers and then witnesses the death of his white father figure and the Aboriginal ancestor he barely knew, a symbolic death of both his worlds. The companionship of a creature that barely bridges the gap between the two provides some comfort. This bridge is signified in later films like Satellite Boy by Pete's love of space and astronauts inadvertently reflecting, and becoming transformed when allied with, Jagamarra's belief that "his modest, transient camp is set on the land under the great starry sky" (Judah 2013, p. 18). The struggle to bridge two identities, we see, is part and parcel of both frontier and contemporary stories, and can be illustrated in both.

In a time where big truths must still be defended in Aboriginal historical discourse (Read 2002, p. 54), the fictional non-liability of film offers a way of telling anomalous stories that aid in encouraging empathy for the multifaceted experiences of Aboriginal people in white society. This experience is translatable across time and valuable for white audiences particularly to see how the process of dispossession is more complicated than one large truth. Wind reflects on a familiar and ongoing struggle for identity of a community living within two worlds, crossing in and out of the "two timelines, two histories of Australia" (Goodall 2002, p. 8). Here, it is the little truths that have the biggest impact.

\section{References}

Blackmore, E. 2014, 'Speakin' Our Blak: New and Emergent Aboriginal Filmmakers Finding Their Voices', in Wendy Gay Pearson \& Susan Knabe (eds) Reverse Shots: Indigenous Film and Media in an International Context, Ontario: Wilfrid Laurier University Press, pp. 61-80.

Goodall, H. 1995, 'New South Wales', in Ann McGrath (ed) Contested Ground: Australian Aborigines Under the British Crown, Allen \& Unwin, St. Leonards, NSW, pp. 55-120.

Goodall, H. 2002, 'Too early yet or not soon enough? Reflections on 'sharing' histories as process not collection', Australian Historical Studies, vol. 33, no. 118, pp. 7-24.

https://doi.org/10.1080/10314610208596176

Judah, T. 2013, 'Call of country: Satellite Boy', Metro Magazine, Iss: 177, pp. 16-20.

Maynard, J. 2005, 'In the interests of our people: the influence of Garveyism on the rise of Australian Aboriginal political activism', Aboriginal History, vol. 29, pp. 1-22.

McGregor, R. 2011, 'Aboriginal Activists Demand Acceptance', Indifferent Inclusion: Aboriginal People and the Australian Nation, Aboriginal Studies Press, pp. 37-54.

Morris, B. 1992, 'Frontier Colonialism as a Culture of Terror', Journal of Australian Studies, Vol.16, no. 35, pp. 72-87. https://doi.org/10.1080/14443059209387119 
Read, P. 2002, 'Clio or Janus? Historians and the stolen generations.', Australian Historical Studies, Vol.33(118), pp. 54-60. https://doi.org/10.1080/10314610208596179

Sen, I. 1999, Wind [Short Film], Canberra: Ronin Films.

Yunupingu, G. 2016, 'ROM WATANGU: The Law of The Land', The Monthly, no. 124, Schwartz Publishing Pty. Ltd, Melbourne.

(c) (1) (C) 2018 by the author(s). This article is distributed under the terms and conditions of the Creative Commons Attribution license (http://creativecommons.org/licenses/by-nd/4.0/). 